\title{
STRUCTURI MODULARE DE COMANDĂ ȘI CONTROL ȘI ORGANIZAREA FORȚEI UTILIZABILE ÎN OPERAȚII LAALTITUDINI MARI
}

\author{
MODULAR COMMAND AND CONTROL STRUCTURES \\ AND FORCE ORGANIZATION USABLE \\ IN OPERATIONS AT HIGH ALTITUDES
}

Col.drd. Cezar POPA*

\begin{abstract}
Abordarea anumitor provocări în zone de operații situate la altitudini mari necesită existența unor capabilități specifice de comandă și control. C2 bazat pe comanda prin misiune trebuie adaptat cerințelor actuale, generate de conflictele cu geometrie variabilă, conflicte de tip mozaic, compozit, multifațetat, multistratificat, multidomeniu. Sistemele de comandă și control ar trebui să dispună de flexibilitate arhitecturală, de platforme digitalizate inteligente, iar modulele sale să fie perfect interoperabile funcțional și acțional (bazate pe autosuficiență - capabilitate extinsă de funcționare în timp). Considerăm că, la altitudini mari, arhitectura unui sistem de comandă și control complex trebuie să fie modulară și concepută ca un integrator coerent de senzori, decidenți, executanţi și capabilități de sprijin, interconectați în subsisteme care să asigure planificarea, pregătirea, executarea și evaluarea cu eficiență a acţiunilor militare. În condiţiile diversificării riscurilor și ameninţărilor în mediul operațional multidimensional, arhitectura sistemelor de comandă și control trebuie adaptată permanent astfel încât să asigure comunicarea în timp real, pe orizontală și pe verticală, între forțe, structurile de sprijin și structurile de comandă-control.
\end{abstract}

Mountainous areas located at high altitudes, hardly accessible, are used as safe heavens and staging areas by various asymmetrical groups. Addressing these challenges in areas of operations located at high altitudes requires the existence of specific capabilities for command and control. C2 based on mission command must be adapted to the current requirements generated by conflicts with variable geometry, mosaic type conflicts, composite, multifaceted, multi-layered, multi-domain conflicts. Command and control systems should have architectural flexibility, intelligent digitised platforms and its modules should be perfectly functionall and interoperable (based on self-sufficiency-extended capability to operate over time). We believe that, at high altitudes, the architecture of a complex command and control system must be modular and designed as a coherent integrator of sensors, decision-makers, performers and support capabilities, interconnected in subsystems that ensure the planning, preparation, execution and effective evaluation of military actions. In the conditions of diversification of risks and threats in the multidimensional operational environment, the architecture of the command and control systems must be permanently adapted in order to ensure real-time, horizontal and vertical communication between forces, support structures and command-control structures.

Cuvinte-cheie: sistem de comandă și control; altitudini mari; operații montane; inteligență artificială; tehnică; tehnologie.

Keywords: command and control system; high altitudes; mountain operations; artificial intelligence; technique; technology.

Pentru a sublinia importanța dezvoltării unor sisteme complexe de C2, adaptate la medii operaționale situate la altitudini mari, am identificat câteva repere istorice reprezentative pentru arta

*Centrul de Perfecţionare Vânători de Munte „Bucegi”

e-mail: cesarp07@gmail.com

militară în ceea ce privește desfășurarea acțiunilor de luptă la altitudini mari, precum și câteva conflicte actuale. Limitările în exercitarea comenziicontrolului şi în executarea operațiilor/acțiunilor militare, identificate prin studiul conflictelor actuale au condus, implicit, la necesitatea dezvoltării sistemelor C2. Capabilitățile specifice necesare unui C2 pentru a asigura succesul în acțiunile/ operațiile executate la altitudini mari argumentează, 
de asemenea, necesitatea dezvoltării acelui sistem de sisteme de comandă și control modular, pornind de la combinarea conceptelor de actualitate cu tehnologia de ultimă generație.

Este cunoscut faptul că peste $25 \%$ din suprafața terestră este acoperită de munți, aproximativ $85 \%$ din granițele lumii sunt clasificate ca fiind montane și aproximativ $12 \%$ din populația lumii trăiește în zone cu altitudini mari. Pe acest considerent, opinăm că este absolut necesară dezvoltarea capabilităților forței care acționează în mediu montan, în special la altitudini mari, și, implicit, a sistemelor de comandă și control aferente. Forțele montane au fost dezvoltate, cu precădere, în ultimul sfert al secolului al XIX-lea, având, în special, misiunea de apărare a granițelor. În 218 î.Hr. armata lui Hannibal a demonstrat o capabilitate neașteptată de trecere a Alpilor și a realizat una dintre cele mai impresionante manevre executate într-o operaţie ofensivă istorică. Primul Război Mondial a confirmat atitudinea defensivă a trupelor de munte, excepții făcând bătălia de la Muntele Krn $(1915)^{1}$ sau cucerirea Muntelui Matajur de către Erwin Rommel ${ }^{2}$. Desfășurarea acțiunilor militare la altitudini mari a condus, deseori, la schimbări de situaţie și a influențat radical rezultatul luptelor ${ }^{3}$. În cel de-al Doilea Război Mondial, acțiunile trupelor de munte s-au desfășurat, în principal, pe vreme rece (campania rusă), dar s-au concretizat și în operații de contrainsurgență în Alpi și în Balcani. De exemplu, bătălia de la Narwik, din Norvegia poate fi considerată o operațiune comună de tip JOINT, care a implicat unităţi marine, forțele aeriene și trupele de munte într-o operație sincronizată. Bătălia de pe Muntele Cassino, de-a lungul liniei defensive germane „Gustav”, din Italia Centrală $\breve{4}^{4}$ ne oferă o altă lecție legată de capabilitățile montane de ducere a acțiunilor de luptă la altitudini mari, care au făcut diferenţa dintre forțele participante ${ }^{5}$ (forțe pregătite pentru asemenea situații și forțe puse în situația de a lupta la altitudini mari pentru prima dată).

La sfârşitul secolului XX și începutul secolului XXI, exemple semnificative de luptă la altitudini mari au fost cele din Asia Centrală (Regiunea Kashmir, scena luptei dintre India și Pakistan pentru ghețarul Siachen, care a dat naștere chiar unui nou concept - ,oropolitică” sau alpinism cu un scop politic). Munții din Afganistan (multe vârfuri depășesc $6.000 \mathrm{~m}$ altitudine, iar platourile montane depășesc deseori 3.000 m altitudine) au constituit zonă de operații în timpul invaziei Uniunii Sovietice din 1979 și al campaniei Enduring Freedom6 6 În zona caucaziană (munţi cu altitudini care depășesc constant $4.000 \mathrm{~m}$ altitudine), armata rusă a reconsiderat capacitatea de manevră a trupelor de munte pentru a-și asigura flancul sudic ${ }^{7}$.

În prezent, există multe conflicte în desfăşurare în mediul montan, la altitudini mari care trebuie monitorizate cu seriozitate. Afganistanul însuși, recunoscut la nivel mondial ca zonă strategică, este încă instabil și este un subiect de interes pentru multe părți implicate ${ }^{8}$. Conflictele de frontieră, cum ar fi cel din India și China ${ }^{9}$ (la peste $4.000 \mathrm{~m}$ altitudine) și cel din regiunea Nagorno-Karabakh (zona Caucazului de Sud), reprezintă, de asemenea, o problemă sensibilă de actualitate. Rutele imigranților din Asia și din Africa către Europa trec, în principal, prin regiuni muntoase, chiar prin zone cu altitudini mari. Alte conflicte identificate la nivel mondial sunt legate, în principal, de surse de apă, de resurse naturale și de infrastructura critică din munți (de exemplu, conflictul din Peru - altitudini peste $5.000 \mathrm{~m}$ ).

În consecință, multe țări sunt într-un proces de adaptare și îmbunătățire a forțelor lor pentru noile scenarii ${ }^{10}$ specifice mediului montan la altitudini mari, în condițiile unui conflict de ultimă generație, cu geometrie variabilă, multinațional, extins și bazat pe oportunități. În acest context, opinăm că dezvoltarea capabilităților necesare desfășurării de operații în acest mediu particular și specific este de actualitate, iar NATO a luat în considerare acest aspect ${ }^{11}$. Se pune problema atât a supraviețuirii forțelor, a manevrabilităţii lor, a sprijinului de orice natură, a creșterii capabilităților de luptă, cât și a unui C2 performant în acest mediu vitreg, din toate punctele de vedere. Pentru forță, acest lucru presupune pregătire specifică, echipament adecvat, precum și o abordare specifică în ceea ce privește doctrina de luptă în mediu montan (în special pentru acțiunile desfășurate la altitudini mari) și tactica utilizată (tehnici și proceduri specifice). Unele state membre ale NATO dezvoltă permanent tehnicile, tacticile și procedurile specifice luptei în mediul montan, însă la nivel de alianță, eforturile sunt limitate (sunt exercitate, la scară redusă, pe litoral, în sprijinul operațiunilor navale din Marea Nordului). 
Limitări în exercitarea comenzii-controlului și în executarea operațiilor/acțiunilor militare la altitudini mari

Relieful montan canalizează deplasările și limitează manevra de forțe și mijloace, iar cel situat la altitudini mari deseori este impracticabil pentru tehnica utilizată la acest moment. Deplasarea sau manevra forțelor debarcate sunt istovitoare pentru resursa umană şi consumatoare de timp.

Clima și vremea rea pot afecta negativ acțiunile/ operațiile executate la altitudini mari, însă pot oferi avantaje tactice indubitabile.

Mediul montan dificil și altitudinile înalte au un efect fizic, fiziologic și psihologic puternic asupra militarilor. Traiul în condiții de izolare și/ sau desfășurarea acțiunilor militare la altitudini mari, fără un antrenament prealabil (de lungă durată) afectează considerabil factorul uman din punct de vedere fizic, fiziologic și psihic. Condițiile nefavorabile de mediu (frigul, umezeala, ceața, ploaia persistentă sau zăpada) duc la instalarea fricii, la depresie și/sau chiar la scăderea moralului factorului uman, implicat atât în actul de comandăcontrol, cât și în cel de execuţie (la nivelul forței). Însă, antrenamentul specific adecvat și condiția fizică foarte bună creează încredere în sine și optimism. Conducerea trebuie să combine raționamentul sănătos cu o înţelegere aprofundată a caracteristicilor mediului montan, ceea ce va duce la obținerea eficienței în actul de comandă. Liderii trebuie să demonstreze capacitatea optimă de a conduce în circumstanțe izolate, teren greu accesibil şi în cele mai dificile condiţii meteorologice pentru a înfrunta impactul fizic, fiziologic și psihologic asupra subunităţilor/unităților.

Din cauza caracteristicilor accidentate ale terenului (suprafețelor mari neacoperite, altitudinilor înalte, văi înguste, versanți abrupți), acțiunile tactice din cadrul unei operații mai ample sunt executate divizat, preponderent cu comandă descentralizată (comanda prin misiune) și cu forțe relativ mici (de nivel grupă, pluton, companie) sau battle grupuri, constituite în funcție de cerințele sau de specificul misiunii (pe principiul forțelor dezintegrate, cu capacitate de integrare rapidă). Putem exemplifica: organizarea de patrule (de recunoaștere, de luptă, sau de urmărire ${ }^{12}$ ), organizarea bazelor de patrulare ${ }^{13}$ sau organizarea forței pe principiul mozaic (parțial sau total robotizate/arme autonome). Aceste forțe, indiferent de modul în care au fost constituite trebuie să se bazeze pe autosusţinere de lungă durată. În aceste situații sprijinul reciproc și relocarea forțelor este foarte dificilă sau chiar imposibilă, iar operarea (comanda-controlul-execuția) separată a acestor elemente este inevitabilă. Ele pot fi conduse centralizat sau descentralizat, dar de cele mai multe ori, acționează descentralizat. Aceste proceduri specifice determină specificitatea C2-ului și a conducerii efective a forțelor pe timpul planificării sau ducerii acțiunilor militare la altitudini mari. Schimbările frecvente și rapide ale vremii duc la schimbarea condițiilor de luptă și de operare și, deseori, necesită o ajustare a planificării operațiunilor, a comenzii-controlului, precum și o schimbare a tehnicilor și tacticilor de luptă. Spre exemplificare, ceața, plafonul jos de nori și precipitațiile determină adesea reducerea bruscă a vizibilităţii, observarea și utilizarea armelor convenționale fiind sever limitate. Forțele dispuse în poziții înalte pot pierde rolul dominant și vor fi obligate să execute manevre de forțe și mijloace spre adversar (se trece la observarea și la lupta apropiată) pentru a îndeplini obiectivele stabilite. În aceste condiții de vreme, elicopterele nu pot fi utilizate sau angajate. Alți factori de mediu care pot influența semnificativ desfășurarea acțiunilor militare/operațiilor în mediul montan: precipitațiile abundente, torentele provenite din topirea zăpezilor, zăpada, creșterea sau scăderea bruscă a temperaturii, grindina, avalanşele sau alunecările minore de zăpadă etc.

Condițiile meteorologice extreme, regăsite la altitudini mari, precum și relieful restricționează mobilitatea, suprasolicită forțele, materialele și echipamentele, care trebuie înlocuite mai des sau substituite cu alt gen de forțe. În contextul acceptării și implementării, la nivelul forțelor care luptă la altitudini mari, a conceptului mosaic warfare $^{14}$ (războiul mozaic), aceste forțe trebuie să fie dezagregate, dar cu capacitate de agregare rapidă pe specificul misiunii, parțial sau total robotizate/ arme autonome, iar sistemele de comandă și control întrebuințate trebuie să fie modulare, manevrabile, să dispună de autonomie energetică mare și să fie asistate de inteligența artificială (IA) prin susținerea arhitecturilor de $\mathrm{C} 2$ cu platforme digitale inteligente. Scopul implementării IA la nivelul comenzii-controlului este optimizarea procesului decizional (creșterea eficienței acestuia prin 
rapiditate, algoritmizare, capacitate incomensurabil mai mare de analiză, sinteză, interpretare date și informații, acces instantaneu la bazele de date etc.) și acela de a deține un control adecvat asupra forței, mai ales a celei parțial sau total robotizate.

\section{Capabilități specifice necesare ducerii} acțiunilor/operațiilor în mediul montan

În momentul actual, accentul se pune pe dezvoltarea și menținerea capabilităților existente, însă opinez că ar fi oportune o previzionare și o dezvoltare implicită a capabilităților necesare pentru a face față noilor provocări ale conflictului modern cu geometrie variabilă, manifestate în toate mediile de confruntare, implicit în mediul terestru montan, la altitudini mari. Este necesar ca aceste capabilități să fie generate pe baza unui concept clar de luptă la altitudini mari, care să genereze o doctrină adecvată și strategii de planificare operațională din timp sau de răspuns la criză (colaborative - extinse la nivelul instituțiilor PMESII, coordonative, multieșalon -, în paralel sau succesiv, bazate pe oportunități sau combinate) care să se plieze pe întreg spectrul de operații desfăşurate simultan sau succesiv ${ }^{15}$. Aceste capabilitătia ar trebui să poată funcționaîntr-o manieră comună (la nivelul NATO) și combinată în medii cu altitudini mari de pe întreg globul pământesc sau comparabile (mediul arctic). Acest aspect ar trebui rezolvat la nivelul de C2 (mai exact C5I2SR), incluzând cooperarea și interoperabilitatea ${ }^{16}$. Este necesar ca acest sistem, pe lângă capabilitățile actuale (comanda și controlul forţelor, imaginea operaţională comună cu interpretarea acesteia, informaţii, supraveghere, cercetare, planificarea operaţională şi tactică, situaţia aeriană și apărarea antirachetă, focul întrunit şi managementul ţintelor aeriene, navale și terestre, managementul efectelor, manevra și sincronizarea, operaţiile informaţionale, protecţia forţei, coordonarea resurselor, asistenţa medicală etc.), să introducă partea de cooperare și interoperabilitate și să extindă partea de recunoaștere și de supraveghere spre macrosupraveghere, cel puțin la nivel regional, dacă nu chiar global, în toate mediile de manifestare a conflictului. Prin crearea unor arhitecturi de sisteme de comandă și control, în care digitalizării și inteligenței artificiale (IA) le este conferit rolul adecvat, se va putea îndeplini acest deziderat. Îmbinarea conceptelor de comandă prin misiune și de război mozaic, utilizarea, la nivel de $\mathrm{C} 2$, a platformelor digitalizate și a inteligenței artificiale, precum și întrebuințarea ultimelor tehnologii în ceea ce privește dezvoltarea armelor autonome, parțial sau total robotizate, vor conduce la generarea acelei forțe dezagregate (cu capacitate de agregare rapidă) și la controlul acesteia pe timpul planificării, pregătirii și executării misiunilor (clasice, chirurgicale sau de orice alta natură), cu eficiență maximă, cu consumuri reduse de resurse, cu reducerea la maximum a pierderilor umane și în orice condiții generate de mediul fizic de confruntare (în cazul de față, situat la altitudini mari). Orientarea spre viitorul conflictelor desfășurate în acest mediu presupune dezvoltarea acestor capabilităţi de comandă și control și de ducere a luptei într-o manieră eficientă și durabilă.

La nivel de planificare operațională, este necesară stabilirea cu precizie a dimensiunilor și structurii forței (pliată pe specificul misiunii) destinate luptei la altitudini mari (viitoarele forțe menite să lupte ar trebui să dețină un ansamblu echilibrat de capabilități, pentru a opera cu succes împotriva unei varietăți de instabilități și amenințări diverse). Generarea forțelor și atribuirea sarcinilor trebuie pe deplin integrate la nivel de comandă și control, în procesul de planificare operațională, la nivelul adecvat (tactic, operativ, strategic). Este necesar ca toate structurile destinate ducerii acțiunilor militare la altitudini mari, precum și sistemele aferente să fie antrenate prin exerciții desfășurate în acel mediu și susținute de proceduri de operare (permanent actualizate sau care să permită adaptarea optimă la schimbările rapide, produse în geometria conflictelor viitorului).

Capabilitățile considerate critice (pentru a acoperi întreaga gamă de alte sarcini care ar putea fi atribuite $^{17}$ ) și necesare îndeplinirii acestui deziderat se pot materializa în:

- exercitarea C2 în operaţiuni comune/ combinate la altitudini mari în toate condiţile meteorologice, în condiții de disponibilitate degradată a spectrului electromagnetic și în perioadele de vizibilitate limitată;

- deplasarea și manevrarea în teren accidentat, situat la altitudini mari, compartimentat, în toate condițiile meteorologice ${ }^{18}$, inclusiv furnizarea de asistență tehnică de luptă pentru mobilitate, contramobilitate și supraviețuire;

- sprijinul prin foc direct sau indirect, realizat cu unităţi organice specializate în operarea la altitudini mari, în toate condițiile meteorologice; 
- realizarea ciclului informaționa $1^{19}$ și operarea ISTAR $^{20}$ în teren dificil, compartimentat și pe vreme variabilă (instabilă), la altitudini mari (context infrastructural degradat sau inexistent), exploatând toate oportunitățile pentru a îndeplini cerințele de informații ale comandantului;

- asigurarea unui nivel adecvat de protecție a forței ${ }^{19}$, sprijinului pentru căutarea, recuperarea personalului și salvarea lui prin integrarea și utilizarea mijloacelor și proceselor specifice mediului operațional, situat la altitudini mari în toate condițiile meteorologice;

- realizarea sprijinului logistic în toate condițiile de teren și vreme;

- aplicarea unei game largi de operații electromagnetice în toate condițiile de teren și vreme;

- generarea forței pentru o gamă largă de acțiuni/operații specifice (forțe interoperabile pentru operațiuni multiple și de lungă durată, în condiţii generate de altitudinile mari și/sau în zonele arctice).

Dacă discutăm doar despre factorul uman, este necesară luarea în considerare a rezilienței și adaptabilității, în scopul rezolvării problemelor legate de stresul și amenințările cu care se confruntă forța. Reziliența ar trebui să fie un scop în sine atât la nivel de individ, cât și la nivel de subunitate. Capacitatea de adaptare trebuie să devină facilă și la îndemâna oricărui luptător. Exercitarea actului de comandă și control/conducere la toate nivelurile este esențială.

Flexibilitatea (capacitatea de dispersare și concentrare a forțelor) într-un mediu montan complex, situat la altitudini mari, este absolut necesară, drept pentru care se recomandă modularitatea (la nivelul structurilor de C2, sistemelor de arme și altor resurse). Organizarea forțelor trebuie realizată astfel încât să dețină putere de foc și autosustenabilitate. Intervenția cu forțe și obținerea necesarului de informații la momentul și la locul dorit sunt necesare pentru a atinge superioritatea critică la momentul oportun, ulterior dispersându-se rapid, pentru a evita contrareacția inamicului. Unitățile mici, agile, puternice și rezistente pot depăși limitarea de mișcare/manevră. Compartimentarea, impusă de caracteristicile terenului, obligă la descentralizarea execuției către unități subtactice. Sistemele/ armele autonome parțial sau total robotizate, controlate de la distanță, unitățile modulare mai mici și munițiile cu letalitate variabilă vor crește indiscutabil această capabilitate. Forțele care acționează la altitudini mari trebuie să fie compuse din unităţi cu pregătire multidomeniu, capabile să execute misiuni specifice în condiții de agregare sau dezagregare de diferite stadii, configurate sau reconfigurate după cerințele și circumstanțele misiunilor ori situațiilor în continuă evoluție sau schimbare. Sistemul de comandă și control trebuie să se plieze pe aceleași cerințe pentru a oferi forței planificarea acțiunii/operației, coordonarea, conducerea și evaluarea, necesare executării misiunii. În contextul conceptului comenzii prin misiune, pentru a opera cu succes în ritmul și la complexitatea cerute de mediul operațional, forțele trebuie să fie capabile să ia decizii rapide și să se adapteze sarcinilor în permanentă schimbare. Este necesară obținerea unei capabilități sporite de reacție/răspuns la situațiile des schimbătoare din evoluția conflictului. Acțiunile decisive cer în mod special (la altitudini mari) descentralizarea execuției și o creștere a abilităților și capabilităților unităților mici și ale comandanților acestora. Comandamentul misiunii trebuie să evolueze (iar acest aspect se poate realiza prin compartimentarea, digitalizarea și modularizarea comenzii-controlului), permițând subordonaților să-și exercite iniţiativa în situații neprevăzute și într-un mediu dispersiv, menținând în același timp intenția neschimbată.

Agilitatea şi imprevizibilitatea manevrei constituie un alt factor care duce la obținerea succesului în lupta la altitudini mari. Este necesar ca C2-ul și forțele să răspundă în mod eficient provocărilor operaționale dinamice și complexe, exploatând oportunitățile prin decizii și acțiuni eficiente și eficace. Pentru factorul uman, prin dezvoltarea abilităţilor specifice alpinismului, fiecare dificultate poate fi rezolvată și se poate obține un efect surpriză. Controlul terenului dominant creează avantajul tactic al constituirii unui nivel ridicat de vulnerabilitate pentru adversar și menține deschisă posibilitatea unei game largi de opțiuni. De asemenea, o infrastructură robustă de comunicații pentru a colecta, a procesa și a difuza informații și pentru a oferi suportul exercitării comenzii-controlului este absolut indispensabilă.

Necesitând un nivel ridicat de mobilitate tactică, unitățile/subunitățile de luptă la altitudini mari nu se pot baza pe sprijin reciproc, iar susținerea logistică este dificilă. Prin urmare, discutăm despre 
necesitatea realizării autosuficienței. Acest aspect se atinge prin constituirea unor forțe de rezervă, substanţiale la toatenivelurile, prin angajareaîn luptă doar a forțelor minime necesare și autosustenabile (pentru un anumit interval de timp), menținând în același timp forțele și activele rămase într-un rol de susținere.

Concretizând, operațiile desfășurate la altitudini mari sunt caracterizate prin angajarea independentă a unităţilor/subunităţilor sau a elementelor tactice constituite (forță dezagregată cu capabilitate de agregare rapidă), prin simbioza ${ }^{22}$ comandă $^{23}$-luptăsprijin (organizarea sarcinilor), prin acțiuni izolate, prin manevra pe verticală, prin necesitatea înlocuirii frecvente a forțelor, prin lipsa infrastructurilor, prin deținerea controlului rețelei de drumuri/transport a defileurilor și înălțimilor/cotelor dominante, prin aprovizionare dificilă (sprijin logistic, realizat cu mare greutate), prin legături dificile sau chiar lipsa legăturilor cu elementele tactice izolate, prin efectul durabil al barierelor ridicate de teren și vreme, prin îngrijire medicală realizată cu dificultate.

În acest context și la această dată (la organizarea actuală și la dotarea actuală a trupelor de munte), se pretează punerea în aplicare a conceptului comandă prin misiune - mission command. În contextul implementării capabilităților specifice conceptului de război mozaic, la nivel de $\mathrm{C} 2$, vom găsi platforme digitalizate și prezența IA, în legătură simbiotică cu forța dezagregată (cu capacitate de agregare rapidă, în compunerea căreia intră arme autonome, parțial sau total robotizate, roboți, drone etc.). Acest aspect va conduce la controlul acesteia pe timpul pregătirii și executării misiunilor (clasice, chirurgicale sau de orice alta natură), cu rapiditate și eficiență maximă, cu consumuri reduse de resurse, cu reducerea la maximum a pierderilor umane și în orice condiții, generate de mediul fizic de confruntare.

Provocarea constă în maniera în care se vor integra, într-un astfel de sistem de sisteme modular și interconectat, cunoștințele extinse despre caracteristicile și cerințele speciale ale acţiunilor militare desfășurate la altitudini mari, capabilitățile, performanța și standardele de performanță, necesare elementelor tactice pentru desfășurarea acțiunilor, tehnicile, tacticile, procedurile, metodele și principiile impuse de caracteristicile mediului și de specificul misiunii, experiența dobândită, modul de gândire flexibil, proactiv și prudent, precum și iniţiativa și efectul de model.
În special, este necesar a fi rezolvate probleme de genul neîntreruperii comunicațiilor, din cauza condițiilor meteorologice și ale terenului, executării manevrei de forțe, mijloace și de foc, dictate de dinamica luptei, reducerii riscurilor cauzate de creșterea tensiunii fizice și mentale a personalului şi de asigurare a echipamentelor suplimentare și a mijloacelor de transport adecvate.

Consider oportun ca sistemele de comandă și control, create pe baza arhitecturilor digitalizate și care au încorporate IA, să atribuie inteligenței artificiale analiza (în cadrul procesului de luare a deciziei) variabilelor, precum: evaluarea corectă și oportună a părților în conflict, estimarea situației inamicului, puterea de luptă și eficacitatea operațională/eficacitatea luptei, gradul de mobilitate a structurilor modulare de C2 și a forței (în special mobilitatea pe verticală), posibilităţile de realizarea a reaprovizionării, canalizarea pe anumite direcții de acțiune, zonele de teren greu accesibil, zonele de angajare izolate, potențialele locuri de aterizare pentru elemente de manevră mici, schimbările rapide produse în dinamica luptei, necesitatea realizării observării la distanță sau în întreaga zonă de operații (observare pe contrapantă, în flancuri și spate), timpul crescut adecvat construirii pozițiilor şi adăposturilor necesare protecției personalului, efectele vremii asupra tehnicii și factorului uman (inclusiv schimbarea condițiilor de vizibilitate) etc. Concret, aceste aspecte se pot transpune în: materiale și echipamente (care trebuie transportate/ furnizate), mobilitate (inclusiv mijloacele de transport), măsuri de conservare a puterii de luptă și utilizarea armelor și muniţiilor.

Crearea și organizarea forței, conform conceptului de război mozaic, ar putea fi o soluție fiabilă pentru aceste cerințe.

\section{Modularitatea sistemelor de comandă și control utilizabile în operații la altitudini mari și necesitatea containerizării acestora}

O organizare eficientă a unui sistem de C2 dislocabil ar putea fi pe module funcționale și pe module integrate. Platformele digitalizate care pot alcătui arhitectura modulară asigură interconectarea (apropiată sau de la distanță) a modulelor pentru obținerea unei planificări colaborative și selective ${ }^{24}$ în același timp. Avantajul principal al modularizării sistemelor de C2 îl constituie faptul că aceste module dețin capabilități de rezolvare a unor 
situații în mod independent (fiecare pe specificul lui), în mod colaborativ selectiv ${ }^{25}$ (pe model rubik ${ }^{26}$ sau mozaic) sau în mod integrat (toate modulele interconectate sau întreg sistemul de sisteme modulare interconectat cu alte sisteme $\mathrm{C} 2$ ).

În accepțiunea noastră, sistemul modular de sisteme este asemenea unui cub rubik. Acesta are posibilitatea schimbării sau adaptării tridimensionale a arhitecturii lui, în functie de tipologia sau de atipologia acțiunii/operației. Folosind aceleași componente, cubul rubik poate afișa un număr considerabil de variante de rezolvare, schimbând, în permanență, fețele sale. În acest sens, sistemul de comandă și control își va schimba rapid structura (fețele), folosind aceleași module (componente) și generând capacitate de adaptare și capabilitățile necesare provocării. Literatura de specialitate oferă la acest moment mai multe variante de organizare modulară a sistemelor de comandă și control. În acest sens, modulele funcționale s-ar putea concretiza în:

- subsistemul modul C2, care cuprinde: comunicații și informatică, managerul de informații, personalul de sprijin decizional și ofițerii de legătură;

- subsistemul modul activități informaționale, format din: PSYOPS, informare și relații publice, informații, CIMIC, război electronic, OPSEC, INFOSEC, operații speciale;

- subsistemul modul informații, la nivelul căruia au loc culegerea, analiza, producerea și diseminarea produselor de informații, produselor cercetării de arme și a acțiunilor de război electronic;

- subsistemul modul protecția forței, în compunerea căruia intră: apărare $\mathrm{CBRN}$, geniu luptă, apărare cibernetică, protecție informații, poliție militară, siguranță și sănătate în muncă;

- subsistemul modul manevră, compus din: operații curente, sincronizare operații, operații viitoare, geniu luptă, planificare, evaluare operații;

- subsistemul modul sprijin prin foc, la nivelul căruia au loc planificarea, coordonarea, integrarea, sincronizarea: angajării adversarului, a mijloacelor letale și nonletale, managementului țintelor, apărării antiaeriane și sprijinului aerian;

- subsistemul modul resurse, compus din: personal, logistică, sprijin medical, sprijin administrativ punct de comandă.

În ceea ce privește modulele integrate, putem aduce în discuție modulul operații curente, modulul operații viitoare și modulul planuri.
Principalele elemente de luptă la altitudini mari sunt sprijinul prin foc și manevra, utilizarea barierelor și lupta pentru superioritatea informațională. Aprecierea comandantului tactic asupra tabloului operațional de la sol este de o importanţă deosebită în procesul de luare a deciziei. Integrarea datelor rezultate în urma executării recunoașterilor în procedurile unui $\mathrm{C} 2$ modular și digitalizat (asistat de IA), precum și transferul rapid și selectiv al datelor și informațiilor în cadrul sistemului de sisteme C2 permit luarea deciziei şi executarea oportună a acțiunilor/operaţiilor. Considerăm că deținerea de către o parte la conflict a superiorității informaționale este cheia asigurării succesului, cel puțin în ceea ce privește activităţile desfășurate la nivel de C2. Schimbul sau transferul de date și informații, obținute efectiv din teren, poate avea impact esențial asupra unui moment al luptei la altitudini mari, dacă decizia este luată în timp oportun. Prin urmare, comanda și controlul trebuie să funcționeze în condiții optime. Una dintre condiții este, așa după cum am prezentat anterior, modularitatea. Din punct de vedere fizic-arhitectural, opinăm că aceste module ar trebui containerizate astfel încât să poată funcționa permanent - static sau în deplasare pe mijloace de transport adecvate terenului, climei şi altitudinilor mari (anumite componente pot fi robotizate, în scopul asigurării accesibilităţii în zone cu altitudine foarte mare, unde organismul uman nu rezistă timp îndelungat). Funcționarea modulelor containerizate (construite pe principiul autosuficienței cel puțin energetice) conduce la exploatarea la maximum a rezultatelor obţinute prin recunoaștere strategică și operațională (pe lângă cele obținute prin recunoașteri proprii), prin recunoaștere în domeniul războiului electronic, prin recunoaștere aeriană și terestră. Aceste date și informații, completate cu rezultatele obținute prin recunoașterile executate în aria de operații, recunoașterea tehnică, supravegherea/controlul spațiului aerian schimbă indiscutabil situația, în favoarea acestui tip de sistem de sisteme modulare de $\mathrm{C} 2$, comparativ cu unul constituit pe model clasic.

Sprijinul prin foc se concretizează prin acordarea lui (alternată și cu rapiditate) atât în luptele apropiate, cât și pentru angajarea inamicului la distanţă. Modulul sprijin prin $f o c$ al unui C2 modular, digitalizat (asistat de IA) și funcțional 
la altitudini mari (containerizat și autosuficient) asigură planificarea, coordonarea, integrarea, sincronizarea angajării adversarului cu mijloacele specifice (letale și/sau nonletale). Managementul țintelor, apărarea antiaeriană și sprijinul aerian sunt sarcini ale acestui modul, care sunt rezolvabile atât în mod independent, dar mai ales în mod integrat, colaborativ atât la nivelul C2-ului din care face parte, dar şi la nivelul altor module similare pe orizontală sau verticală. Este esențial a se realiza acest mod de lucru integrat și colaborativ, din cauza barierelor impuse de caracteristicile terenului la altitudini mari și de schimbările frecvente ale condițiilor meteorologice, sistemele trebuind să fie interconectate atât pe orizontală, cât și pe verticală pentru a se putea substitui sau sprijini reciproc. În funcție de dinamica luptei, pot fi angajate alternativ sau simultan artileria de munte, armele autonome parțial sau total robotizate, armamentul de pe mașinile de luptă etc.

In ceea ce privește manevra, terenul situat la altitudini mari restricționează mișcările și le canalizează în foarte mare măsură. Viteza de deplasare este redusă, iar axele de mișcare pot fi întrerupte de obstacole naturale (râuri umflate de munte, alunecări de teren și avalanșe). Modulul manevră al unui $\mathrm{C} 2$ specific zonelor situate la altitudini mari, pentru a fi performant, trebuie să funcționeze pe toate componentele sale. Din punct de vedere tehnic, opinăm că, pentru a obține capabilitatea de manevră a C2-ului în zone situate la altitudini mari, atât sistemul în totalitatea lui, cât și modulele sale ar trebui să poată funcționa și separat, și integrat, dar conexiunea să se realizeze la distanță. Spre exemplificare, factorul uman și platformele digitale aferente modulului manevră, $\mathrm{cu}$ submodulele sale funcționale și/sau integrate (operații curente, sincronizare operații, operaţii viitoare, geniu luptă și planificare şi evaluare operații) trebuie să fie distribuite pe containere separate, mai mici, mai ușor de transportat de către mijloace specifice de transport, la altitudini mari și foarte mari. Dispersate pe o anumită rază de acțiune electromagnetică, acestea se pot interconecta și lucra în condiții de protecție a forței și de manevrabilitate ridicată. Manevrabilitatea micilor subansambluri și autosuficiența lor ridicată sunt pretabile la altitudini mari pe același considerent pentru care există necesitatea planificării și executării acțiunilor de luptă de către structuri tactice mici, ușor manevrabile și cu putere de foc mare. Metoda de luptă care se pretează în aceste situații este manevră separată acțiune întrunită. Manevra trebuie să fie planificată minuţios, recunoscută și pregătită în timp util. Planificarea este relativ dificilă și necesită multă experiență. Manevra trebuie executată în așa fel încât să fie îndeplinită misiunea și să fie, în același timp, asigurată sustenabilitatea.

Protecția forței la altitudini mari și supraviețuirea militarilor sunt determinate de calitatea infrastructurii și a echipamentelor existente mai mult decât în oricare alt mediu de confruntare. Pentru a asigura prezența operațional - tactică în întreaga zonă de operații montană pe o perioadă prelungită de timp, sistemele de comandăcontrol și forțele trebuie să dețină capabilitatea de supraviețuire, în scopul menținerii capacității de luptă. Protecția pasivă și activă crește șansa de supraviețuire. Modulul protecția forței de la nivelul C2 trebuie să funcționeze și să acționeze la fel ca celelalte module discutate anterior. Principiul ar fi submodularitatea funcțională și acțională pe: apărare CBRN, geniu luptă, apărare cibernetică, protecție informații, poliție militară, siguranță și sănătate în muncă. Gestionarea situațiilor specifice prin măsuri de protecție pasivă ${ }^{27}$ și măsurile de protectie activă $\breve{2}^{28}$, ca parte a conducerii directe, se manifestă pe timpul activităților de recunoaștere, executării patrulelor de luptă, de urmărire, pe timpul constituirii bazelor de patrulare sau întrebuințării eficiente a rezervelor. Aclimatizarea este foarte importantă pentru factorul uman (ca una dintre problemele majore) și trebuie să facă parte din planul operațional. Acesta include, de asemenea, şi pregătirea rezervelor și înlocuirilor. Înlocuirile forțelor la cote înalte prin transportul aerian, fără aclimatizare în prealabil nu funcționează. Personalul este compromis din start din punctul de vedere al sănătăţii fizice și mentale.

În ceea ce privește comunicațiile, ca parte componentă a modulului $\mathrm{C} 2$ din cadrul sistemului de comandă și control, acestea sunt condiționate restrictiv de către zonele situate la altitudini mari. De cele mai multe ori, se impune utilizarea stațiilor de releu și a altor elemente de legătură (ofițeri de legătură, patrule de luptă etc.), pe lângă subsistemele de comunicații și de informații ale C2. Elicopterele sunt des utilizate pentru misiuni de cercetare, recunoaștere, pentru posturi de comandă mobile şi pentru stabilirea personală a contactului dintre 
comandanți, însă nu întotdeauna pot fi întrebuințate pe considerente de vreme și de vulnerabilitate în fața adversarului. Prin urmare, susținem din nou posibilitatea utilizării sistemelor de comunicaţii pe model submodular funcțional pe sisteme robotice sau parţial robotizate, cu capabilităţi extinse de a executa manevra și de a se autosusține timp îndelungat în zonele situate la altitudini mari. Măsurile adoptate pentru asigurarea durabilității, aprovizionării, infrastructurii adecvate, protecției impotriva factorilor de mediu montan, precum și măsurile $\mathrm{C} 2$, adoptate pentru păstrarea puterii de luptă, sunt de o importanță decisivă în desfășurarea acțiunilor militare în acest tip de mediu de confruntare.

La nivelul procesului de planificare operaţională din cadrul modulului resurse (personal, logistică, sprijin medical, sprijin administrativ punct de comandă), în estimarea situației logistice, opinăm că trebuie implicat personal cu experiență în operațiuni montane, dar și platforme digitalizate și asistate de IA (dacă se dorește implementarea conceptului de planificare centrată pe decizie (cum ar fi războiul mozaic), pe lângă acela de comandă prin misiune. O desfăşurare de elemente/forțe care luptăautonomînzoneizolate, combinată cupericolul ca lanțurile de aprovizionare să fie întrerupte, necesită o sustenabilitate logistică, bazată pe autosuficiență și pe autosusținere (aprovizionarea nu poate fi garantată). Prin urmare, planificarea trebuie realizată pe autosuficiență, durabilitate, iar elementele de manevră independente trebuie să fie întărite de forțe logistice de aprovizionare, cu abilități și capabilități montane și/sau forțe manevriere (pe sol sau în aer), dezagregate parțial sau total robotizate (cu capabilitate de agregare și acțiune rapidă). La momentul actual, elicopterele sunt cel mai eficient mijloc de transport la cote înalte, însă este un mijloc de tip monolitic ${ }^{29}$ (descoperire-determinare, decizie și acțiune), care, odată compromis, va compromite sarcina/misiunea atribuită. În orice caz, utilizarea elicopterelor poate fi restricționată de vremea rea, de altitudine ridicată și de activitățile inamicului. Pentru cât mai mult timp posibil, ar trebui exploatate avantajele autovehiculelor pentru aprovizionare și toate celelalte mijloace de transport adecvate (cum ar fi tractoare, utilitare, camioane cu platformă, vehicule de zăpadă, quaduri, snowmobile, transport pe cablu, animale de transport, roboți, drone etc.). Modulul resurse din cadrul C2 gestionează recunoașterea, înființarea și securizarea echipamentelor speciale și specifice de evacuare din acest mediu situat la altitudini mari atât pentru tehnică, cât și pentru personal (în condițiile existenței riscului căderii în prăpăstii a personalului evacuat sau a vehiculelor tractate si/sau avariate.

Intreținerile și reparațiile $\mathrm{nu}$ este indicat a se realiza la altitudini mari, decât dacă sunt luați în calcul roboții ca mijloace de executare a reparațiilor. Obiectivul este de a asigura gradul necesar de disponibilitate a materialului, precum și disponibilitatea operațională a dispozitivelor, armelor și echipamentelor. Din punctul de vedere al înlocuirii (la nevoie) a resursei umane, personalul de inlocuire trebuie să fie acela care a urmat aceeași pregătire în mediu situat la altitudini mari și trebuie să dețină aceleași echipamente cu cele ale forțelor deja dislocate a căror înlocuire este necesară. Condiţiile generate de un mediu îngreunează substanţial acordarea de asistență medicală.

Nevoia unei noi abordări a luptei la altitudini mari este absolut necesară. Astăzi, cele mai semnificative provocări operaţionale cu care se confruntă forțele într-un astfel de mediu includ cele legate de senzori și rețele și cele legate de arme autonome cu precizie mare, parțial sau integral robotizate. De exemplu, China folosește aceste capabilități ca parte a unui sistem cuprinzător de sisteme, concepute pentru a ataca vulnerabilitățile percepute în forțele adverse. Iar Rusia își completează armele și senzorii de precizie cu rază lungă de acțiune, forțele proxy și paramilitare, pe care le folosesc pentru a pune în aplicare tactici de ,zonă gri” ${ }^{30}$, pentru a câștiga teritorii și influență prin contestarea teritoriilor în litigiu sau destabilizarea țărilor vecine ${ }^{31}$.

În loc să distrugă forțele unui adversar până când acesta nu mai poate lupta sau nu mai poate reuși, o abordare a războiului centrată pe decizie ar impune multiple dileme unui inamic pentru a-1 împiedica în atingerea obiectivelor sale. Războiul bazat pe manevre clasice este conceput pentru a zădărnici operațiunile inamicului prin perturbarea centrelor sale de greutate, cum ar fi sustinerea sau comanda și controlul $(\mathrm{C} 2)^{32}$. Acest lucru poate fi privit ca un atac asupra coeziunii unei rețele de luptă adversare ${ }^{33}$. Trecerea către abordarea luptei/ conflictului desfășurat în zone situate la altitudini mari, prin concepte centrate pe decizii rapide este inevitabilă. În antiteză, războiul centrat pe rețea se 
bazează pe comandanții de teatre de operații (pe conștientizarea de către aceștia a situației/situațiilor pe zone largi și pe capacitatea de a comunica cu toate forțele aflate sub comanda lor). Însă luarea centralizată a deciziilor nu va fi nici posibilă, nici de dorit pe timpul desfășurării conflictelor viitoare în medii extreme, precum cel situat la altitudini mari. Îmbunătăţirea capabilităților adversarului în ceea ce privește războiul electronic (EW), a altor capabilităti contra-C2 și de informații, supraveghere și recunoaștere (C4ISR) va reduce capacitatea comandanților de a înțelege situațiile nou create sau de a comunica în zona de operații, mai ales în cea situată la altitudini mari (din cauza factorilor naturali de mediu). Aceste acțiuni vor îngrădi capacitatea comandanţilor de a exercita controlul asupra unor grupuri de forțe din subordine.

În timp ce războiul centrat pe rețea presupune un grad ridicat de claritate și control, războiul centrat pe decizii (generate de oportunităţi) induce nesiguranța în forțele adverse și îmbunătățește adaptabilitatea și supraviețuirea forțelor proprii prin valorificarea distribuției forței, prin compunere şi recompunere dinamică, prin reduceri ale emisiilor electronice și prin acțiuni contra C4ISR. Aceste aspecte conduc la o creștere substanţială a complexității și incertitudinii pe care le-ar avea un adversar în procesul propriu de luare a deciziilor. Sistemele de arme autonome (vehiculele fără pilot) și gestionarea sistemelor rețelelor de comunicații ar putea ajuta forțele să execute acțiuni dispersate, cu efecte devastatoare asupra adversarului. Utilizarea sistemelor autonome gestionate de IA la nivel de C2 permit agregarea forței, în funcție de specificul misiunii, pe principiul economiei de forțe și de mijloace (dezagregarea capabilităților platformelor şi unităţilor tradiţionale cu mai multe misiuni într-un număr mai mare și mai puțin multifuncționale și costisitoare). În acest context, suntem de părere că este necesar ca sprijinul decizional să se realizeze cu ajutorul IA. Războiul centrat pe decizii abordează limitările comenzii prin misiune cu o nouă structură de C2, care combină comanda umană cu controlul inteligenței artificiale. Decizia bazată pe implicarea IA și pe instrumentele de sprijin aferente ar permite comandanților să controleze forțele dispersate, să se adapteze la acțiunile de mediu situat la altitudini mari sau la cele ale adversarului și să impună complexitate în luarea deciziilor de către inamic. Conceptul de „război mozaic” (Mosaic Warfare) oferă o abordare a conflictului, axată pe deciziii ${ }^{34}$, care poate fi extinsă cu succes în mediu conflictual, situat la altitudini mari. Ideea centrală a războiului mozaic este aceea de a crea adaptabilitate pentru forțe și complexitate sau incertitudine pentru inamic prin compunerea și recompunerea rapidă a unei forțe militare dezagregate care utilizează comanda umană și controlul maşinilor. Implementarea conceptului de război mozaic sau a altor concepte de război centrate pe decizie va necesita modificări substanțiale ale proiectării forțelor, ale structurilor, arhitecturilor și proceselor C2. Dacă proiectarea forței se va realiza fără modificarea procesului $C 2$ asociat, comandanții și personalul statului major vor avea dificultăţi în gestionarea unui număr mai mare de elemente dintr-o forţă dezagregată, în comparație cu o forță tradiţională. Fără sisteme de control automatizate și asistate de IA, comandanţii ar fi mult mai puțin în măsură să gestioneze corect noile structuri de forțe, rezultate în urma centrării pe decizie (pentru crearea complexităţii pentru adversar), sau recompunerea forței, ca răspuns la acțiunile inamicului şi la contramăsurile acestuia. În Figura 1, este ilustrat un model de comandă umană, de proces de luare a deciziei, asistat de către IA (participă la elaborarea cursurilor de acțiune și a organizării, pentru misiune, a forței) și de control, exercitat prin inteligență artificială asupra execuției misiunii de către forța agregată pe specificul misiunii.

Perspectiva prezentată în exemplul anterior a fost validată prin trei jocuri de război, efectuate de CSBA (Center for Strategic and Budgetary Assessments), care au comparat, în cadrul unor scenarii plauzibile, de mare putere și pliate pe un viitor potențial conflict regional ${ }^{36}$, performanțele obținute de sistemele de C2 şi de forțele convenționale ale SUA și de forțele de tip mozaic (cu procesele de C2 aferente). Jocurile de război au fost construite pentru a testa cinci ipoteze privind fezabilitatea și beneficiile operaționale ale conceptului de război mozaic ${ }^{37}$ : comandanţii și planificatorii pot obține încredere într-un sistem de control activat de mașini; Mozaic Warfare va crește complexitatea pachetelor de forțe și va degrada luarea deciziilor adversarului; Mosaic Warfare va permite comandanților să angajeze mai multe acțiuni simultan, creând o complexitate suplimentară pentru adversari și îngreunând procesul de luare a deciziei; designul forței mozaic și procesul C2 


\section{EXEMPLARY CONTEXT - CENTRIC C3 APPROACH ${ }^{35}$}

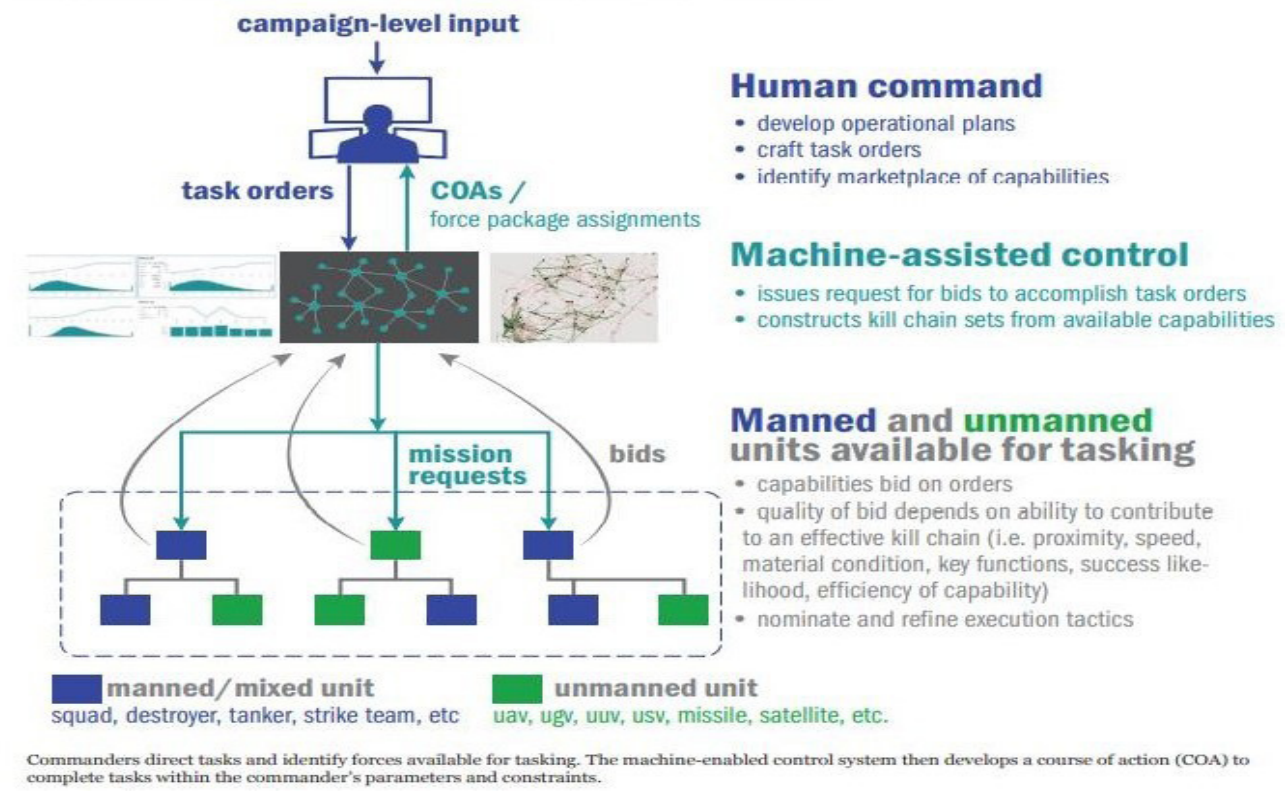

Figura 1 Exemplu de sistem Context-Centric C3, care utilizează comanda umană și controlul inteligenței artificiale asupra forței dezagregate cu capabilitate de agregare pe specificul misiunii

vor crește viteza de reacție a forțelor și viteza procesului de luare a deciziilor; războiul mozaic va mai permite comandanților să aplice procedee și tactici de luptă, strategii variate, în comparație cu cele executate cu o forță tradițională.

O altă oportunitate oferită de conceptul de război mozaic este executarea acțiunilor sau operațiilor prin manevre. Forțele ar putea crea incertitudine adversarului și ar descuraja agresiunea prin folosirea unor abordări centrate pe decizie, cum ar fi manevrele succesive și/sau simultane, executate cu forțe de tip mozaic. Două aplicații fundamentale ale războiului de manevră sunt dislocarea sau împiedicarea inamicului de a atinge obiectivul propus la momentul dorit și perturbarea sau atacarea centrului de greutate al inamicului. Acest lucru poate fi privit ca atacând coeziunea unei rețele de luptă a adversarului.

Concluzionând, afirmăm faptul că toate aceste provocări, provenite, în special, din ducerea acțiunilor militare în mediul situat la altitudini mari, pot fi gestionate de sisteme de comandă și control modulare, digitalizate și asistate de inteligența artificială, în condițiile în care se va aborda lupta, combinând cele mai noi concepte specifice conflictelor de ultimă generație cu cele mai noi descoperiri din domeniul tehnicii și tehnologiei.

\section{Combinarea conceptelor cu tehnologia}

Tehnologiile de susținere oferă îmbunătățiri progresive sistemelor actuale și folosesc mecanisme similare pentru a obține efecte de luptă. Tehnologiile disruptive utilizează noi mecanisme pentru a oferi valoare militară, folosind vectori diferiți față de tehnologiile precedente. De exemplu, la un radar actual, jammerul ${ }^{38}$ poate fi evaluat (ca și predecesorii săi) după cât de bine ascunde sau induce în eroare ținta. Pe de altă parte, performanța unei platforme stealth ${ }^{39}$ este evaluată în funcție de cât de bine aceasta evită să fie detectată sau vizată de radar. Noile tehnologii de susținere sau disruptive pot fi combinate cu concepte operaționale evolutive, care introduc schimbări în utilizarea ori în capabilitățile tehnicii (cum ar fi folosirea radarului pentru localizarea mijloacelor de navigație), sau revoluționare, concepte operaționale care urmăresc obiective militare în moduri cu totul noi (cum ar fi utilizarea satelitului pentru navigare). O modalitate de a vizualiza relaţia dintre tehnologii și concepte operaționale este prezentată în Figura $2^{40}$. Este realizată o paralelă între tehnologiile de susţinere și cele disruptive pe baza conceptelor revoluționare și evoluționiste, fiind surprinsă și o parte din efectele rezultate. 




Figura 2 Inovații militare, rezultate din combinarea tipurilor de tehnologii cu noile concepte de luptă

Eforturile recente de a dezvolta IA și sisteme autonome s-au concentrat, mai degrabă, pe îmbunătătirea modurilor de operare decât pe dezvoltarea a noi concepte de luptă. De exemplu, Project Maven, un program timpuriu, activat de DoD (Department of Defense al US), folosește IA pentru a îmbunătăți viteza şi acuratețea în interpretarea imaginilor, în comparație cu analiștii umani. Multe dintre aceste imagini sunt adunate de senzori autonomi prin satelit sau UAV, care îndeplinesc aceleași funcții ca și cei cu echipaj pe aeronave, dar care pot face acest lucru mai mult sau pe zone mai largi. Această abordare, nu în mod fundamental, schimbă modul în care DoD adună sau utilizează informații. Senzorii Maven și autonomi combină arme de precizie și senzori în rețea și gestionează informații diferit pentru a obține un avantaj substanțial în luarea deciziilor ${ }^{41}$.

Superioritatea deciziei, adoptată prin arhitecturile de comandă-control specifice conceptului de război mozaic, pleacă de la ideea centrală a conceptului, și anume aceea de a crea adaptabilitate şi flexibilitate forțelor și complexitate sau incertitudine pentru un inamic prin compunerea rapidă și recompunerea, la nevoie, a forțelor dezagregate care folosesc comanda umană și controlul inteligenței artificiale.

Schimbările semnificative necesare proiectării forțelor, arhitecturilor și proceselor C2 vor fi dificil de implementat cu rapiditate în mediul conflictual situat la altitudini mari. În consecință, se poate stabili, inițial, o forță experimentală care să acționeze într-un astfel de mediu, să execute acțiuni specifice conceptelor operaționale centrate pe decizie şi comenzii prin misiune, în scopul evaluării eficienței și eficacității. Această metodă a fost folosită, în timpul schimbărilor anterioare, în armata SUA (dezvoltarea AirLand Battle de către armata SUA și punerea în practică a capacităților de lovire în ascuns și cu precizie de către US Air Force $)^{42}$. La acest moment, majoritatea forțelor existente la nivel mondial sunt constituite din unități multimisiune cu echipaj, cum ar fi avioanele, nave și formațiuni de trupe autonome sau monolitice, încorporând proprii lor senzori, capabilități C2 și arme sau sisteme electronice de luptă. În armata 
SUA, elementele de forță care nu sunt unități autonome multimisiune trebuie să facă parte dintrun sistem de sisteme - SoS (system of systems) - prearhitectat, în conformitate cu cerinţele DoD şi cu politicile de achiziţie ${ }^{43}$. Configuraţia relativ inflexibilă a unităţilor multimisiune monolitice, comparativ cu a SoS, limitează varietatea de moduri de acțiune pentru acea forță, reduce adaptabilitatea forței, acțiunile/operațiile executate sunt previzibile și scade probabilitatea de a induce în eroare inamicul (ca parte a conceptelor operaționale axate pe obținerea unui avantaj de luare a deciziilor). Prin descompunerea unora dintre unitățile monolitice de luptă, UAV-uri echipate cu senzori și aparatură de război electronic (EW). O forță care acționează la munte ar putea fi constituită din formațiuni mici care acționează utilizând drone de luptă, UGV-uri și/sau UAV-uri pentru a-și îmbunătăți capacitatea de autoapărare, ISR și logistică.

În Figura 3, este prezentată diferența dintre o unitate de tip monolit și o forță agregată pe specificul misiunii (composable force - este termenul utilizat în literatura de specialitate a Armatei SUA) din punctul de vedere al actului de descoperiredeterminare țintă, decizie și acțiune (sense, decide, $a c t$ ). Dezagregarea unităților cu mai multe misiuni

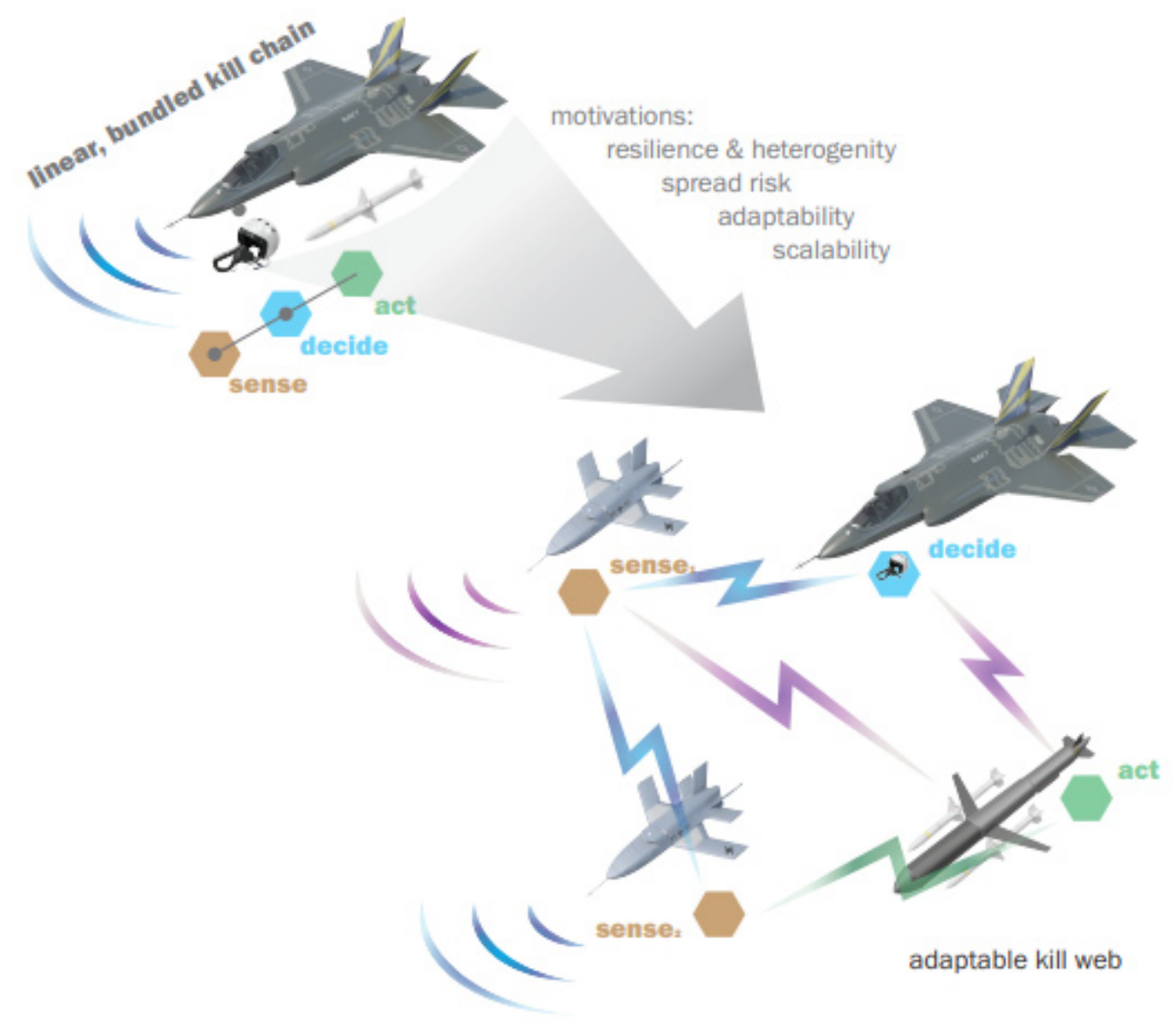

Disaggregating multi-mission units could increase the flexibelity and adaptability of the force and create a more complex situation for the adversary to assess. In this graphic, traditional 'monolithic' strike-fighter (left) is replaced with a more composable force package (right) in which the strike-fighter acts as a $\mathrm{C}_{2}$ node for one or more groups of UAVs.

Figura 3 Unități monolitice versus pachete de forță agregată pe specificul misiunii ${ }^{44}$

multimisiune de astăzi într-un număr mai mare de elemente mai mici, cu mai puține sarcini, s-ar putea urmări mai bine decizia și superioritatea informațională și s-ar obține efectul scontat în derutarea adversarului.

De exemplu, la altitudini mari, un grup de luptători ar putea fi înlocuit cu un luptător care acționează ca o platformă C4ISR, împreună cu drone ar putea crește flexibilitatea și adaptabilitatea forței și ar putea crea o situație complexă pentru adversar. Luptătorul tradiţional „monolitic” (stânga) este înlocuit cu un pachet de forțe agregat pe specificul misiunii (dreapta), în care atacatorul acţionează ca un nucleu C2 (comandat de factorul uman și controlat de IA) pentru unul sau mai multe grupuri de UAV. Acest aspect este ilustrat în Figura 3. 


\section{Concluzii}

Unitățile destinate să lupte la altitudini mari sunt desemnate să execute acţiuni/operaţii specifice într-un mediu extrem de ostil. Factorul uman angajat în luptă trebuie să dețină echipament special și trebuie să fie instruit în condițiile de teren și de vreme specifice acestui mediu. C2 la altitudini mari trebuie să fie capabil să exercite comanda și controlul în operații în toate condițiile meteorologice, sub cupola unui spectru electronic degradat și în condiții vitrege de vreme (ceață, îngheț, viscol etc.). Această capabilitate necesită un proces de planificare operațională complex și atribuirea de sarcini specifice pentru executarea acțiunilor/operațiilor în orice condiții de vreme. $\mathrm{O}$ imagine operațională comună mediului conflictual situat la altitudini mari este o componentă cheie pentru comanda, controlul forțelor de tip monolit, dar, cu precădere, pentru forțele composabile, angajate în acțiuni/operații.

Propunem două variante de constituire a forței și de exercitare a comenzii controlului:

- subunităţi întărite, special constituite pe specificul misiunii (mici, suple, mobile, cu autosustenabilitate mare, cu putere mare de foc și manevrabilitate mare), dispunând de un C2 modular, dar susţinut de arhitecturi și platforme clasice (bazat pe conceptul comenzii prin misiune);

- forțe dezagregate cu capabilitate de agregare rapidă (în funcție de specificul misiunii), în compunerea cărora să intre și arme autonome parțial sau total robotizate, asupra cărora să se exercite comanda umană și control prin inteligență artificială, implementată la nivelul unui sistem de sisteme de comandă și control de tip modular, susţinut de platforme digitalizate și acțional în accepțiunea conceptului de război mozaic (bazat pe decizie), specific conflictelor cu geometrie variabilă.

Valorificarea tehnologiilor disruptive, inteligenței artificiale și sistemelor autonome constituie noua arenă de competiție pentru armatele moderne. Noile concepte operaționale vor fi esențiale, în scopul exploatării pe deplin a potenţialului acestor tehnologii. IA și sistemele autonome nu trebuie să rămână doar la stadiul de mijloc de îmbunătățire a abordărilor operaționale actuale. Concepte operaționale centrate pe decizii, cum ar fi conceptul de război mozaic, ar putea valorifica beneficiile IA și ale sistemelor autonome, reducând în același timp impactul dezavantajelor potenţiale ale acestora. De exemplu, prin dezagregarea platformelor monolitice (cu echipaj) și a formaţiunilor de trupe în unităţi mai mici, mai puțin multifuncționale, proiectarea forței centrate pe decizie ar reduce presiunea pusă pe un sistem autonom individual, necesară înlocuirii unei întregi platforme multi-misiune. Combinând comanda umană cu controlul conferit procentual inteligenței artificiale, $\mathrm{C} 2$ va procesa algoritmii de luare a deciziilor, va valorifica creativitatea umană în executarea sarcinilor, va aloca forțele necesare executării sarcinilor și va orchestra cu ușurință acțiunile militare ca parte a unei operații. Mai mult decât atât, utilizând în procesul de planificare scenariile predictive (la care IA va avea un aport substanțial atât în analiză, cât și în previziune), se va evita la maximum surprinderea și se vor crea anticipat soluții de rezolvare a situațiilor posibile, probabile și iminente.

Punerea în aplicare a conceptelor operaționale centrate pe decizie va fi probabil evolutivă. În ceea ce privește desfãșurarea acțiunilor militare la altitudini mari, s-ar putea adopta, în primă fază, un design al forței, centrat pe decizie și un sistem C2 (modular şi digitalizat), cu un proces aferent (procedural, algoritmic, dar și intuitiv, bazat pe experiență și cunoștințe), care să pună în aplicare conceptul de comandă prin misiune. Conceptele centrate pe decizie pot să nu corespundă în totalitate cerințelor noilor tipuri de conflicte, dar pot fi dezvoltate, combinate sau înlocuite cu alte concepte noi, în funcție de evoluția continuă a tehnicii și tehnologiei și în funcție de evoluția conflictelor. Cert este faptul că sistemele de comandă și control trebuie să se bazeze pe arhitecturi modulare și pe platforme digitalizate (susținute în procesul de planificare operațională și în execuție de către inteligența artificială), care să le permită adaptarea perpetuă la cerințele conflictului cu geometrie variabilă. Considerăm că organizarea de tip modular şi submodular a unui sistem de sisteme de comandă și control, destinat ducerii acțiunilor militare la altitudini mari și nu numai, construit pe baza unor arhitecturi de tip rubik sau mozaic (care să le permită combinarea și recombinarea lor rapidă, în funcție de specificul misiunii sau de situația concretă reală sau previzionată) și susținut de platforme digitale inteligente (în care IA este implementată cu rol clar definit în procesul decizional și în controlul 
forței), este varianta care oferă o soluție optimă în asimetria și imprevizibilitatea situațiilor generate de conflictele moderne, multifațetate și cu o geometrie a acțiunilor extrem de variabilă.

\section{NOTE:}

1 Regimentul 3 trupe alpine italiene a executat noaptea un atac surpriză. Folosind cele mai dificile rute, a reușit să cucerească acest vârf important din punct de vedere strategic.

2 Celebrul raid în care Batalionul de Munte Württemberg a reușit să se infiltreze în tranșeele italiene.

3 În 1915, Înaltul Comandament Italian nu a exploatat în mod adecvat avantajul obținut și a trecut treptat la cucerirea pozitiilor ulterioare, în conformitate cu doctrina vremii. Doi ani mai târziu, exploatarea la timp a decalajului de către trupele austro-ungare și germane a provocat prăbuşirea întregului front de est italian.

4 Lanțul de munți Apenini, apărat impecabil de forțele generalului Kesselring, s-a dovedit a fi un obstacol de netrecut în calea mult mai numeroaselor divizii aliate.

5 Parașutiștii germani au câștigat o experiență importantă în Apenini, care le-a permis să reziste atât de mult timp. Trupele de munte, sosite de pe frontul rus, nu au fost la fel de eficiente, deoarece, fiind dislocate pe stepă de mult timp, nu erau obișnuite să lupte în medii impracticabile și compartimentate.

6 Într-un interviu celebru, generalul Massod, eroul Panshirului, când a fost întrebat cum a reușit să reziste atât de mult timp cu câțiva luptători slab înarmați în fața celor mai numeroase şi mai puternice forțe armate ale lumii, a răspuns că puterea lor stă în natura acelui loc, văi înguste și munți asprii, "How Afghanistan defeated the Soviet Union", Deutsche Welle, 2021.

7 Blandy, North Caucasus: The Advent of Mountain Brigades, Defence Academy of the United Kingdom, 2007, pp. 1-5.

$8 \mathrm{http} / /$ unep.ch/publications/UNEP_Afghanistan_NRM guidance, 2021, accesat la 09.11.2021.

9 Zona Ladakh, de-a lungul liniei de control real (LAC), unde vedem confruntarea dintre aceste superputeri emergente.

$10 * * *$ Russian Exoskeleton Project, Russia's latest combat exoskeleton to boost fire accuracy by 20\%, TASS Russian news agency, 2021.

$11 * * *$ Brussels Summit Declaration, 2018.

12 Patrula de recunoaștere - asigură comandantului informații la timp și precise despre inamic și teren, în vederea producerii unui plan (pot fi de două tipuri, pentru cercetarea itinerarelor sau pentru cercetarea zonelor); patrula de luptă - este necesar ca orice subunitate de nivel pluton întărit corespunzător să poată executa misiuni, precum ambuscada și raidul (absolut necesare în teren muntos și se concretizează în sarcini precum: distrugerea/capturarea adversarului sau echipamentelor /instalaţiilor militare; hărțuirea adversarului; asigurarea protecției/securității eșaloanelor superioare); patrula de urmărire - plutonul sau grupa poate primi misiunea să urmărească/găsească adversarul care a rupt contactul, în vederea restabilirii contactului cu acesta.
13 Baza de patrulare - poziție organizată la nivel grupă/ pluton pe timpul haltelor sau pentru o perioadă mai lungă (nu mai mult de 24 h și nu se ocupă niciodată de două ori aceeași poziție) pentru controlul obiectivelor importante şi pregătirea viitoarelor acțiuni decisive (oferă avantajul acoperirii cu subunități mici a unor zone mari și deținerii controlului acestora).

14 Bryan Clark, Dan Patt, Harrison Schramm, Mosaic warfare exploiting artificial intelligence and autonomus system to implement decizion - center operations, Center for Strategic and Budgetary Assessments, 2020, pp. 8-13, 56-58.

15 Cezar Popa, Strategii, concepte și procedee de eficientizare a procesului decizional, Raport de cercetare științifică nr. 2, Universitatea Naţională de Apărare „Carol I”, București, 2021, p. 22.

16 Niculai-Tudorel Lehaci, Tendințe în evoluţia sistemului de comandă și control la nivel operativ, Editura Universității Naționale de Apărare „Carol I”, București, 2015, p. 65.

17 Răspuns rapid, operațiuni de control în zona arctică/ subarctică sau urbană.

18 Inclusiv condiții arctice.

19 Ciclul de informații cuprinde direcția, colectarea, prelucrarea și diseminarea (NATO Allied Joint Doctrine for Intelligence Procedures AJP-2.1).

20 ISTAR - Intelligence, Surveillance, Target Acquisition and Reconnaissance - Informaţii, Supraveghere, Achiziție ținte și Recunoaştere (NATO Allied Joint Doctrine for Intelligence, Counter-Intelligence and Security AJP-2(A)).

21 Aceasta include implementarea politicilor şi standardelor de apărare aeriană, OPSEC, INFOSEC, COMSEC, de apărare cibernetică, CBRN, CIED și de protecție a sănătății.

22 Simbioza se realizează și la nivelul acțional (comandăluptă-sprijin) și la nivelul om-inteligență artificială-maşină (sisteme C2-arme autonome parțial sau total robotizateroboți- drone- sateliți- etc.).

23 În accepțiunea termenului comandă în acest context, doresc să cuprind sistemele modulare de comandă şi control, construite pe arhitecturi complexe digitalizate, în care este implementată inteligența artificială și care sunt în strânsă legătură (simbiotică) cu elementul de conducere/comandă al forței/elementului de execuție.

24 Sunt angrenate în procesul de planificare operaţională doar modulele de care este nevoie la un moment dat, în funcție de timpul avut la dispoziție, de specificul misiunii și/ sau de situația concretă din teren.

25 Se interconectează acele module de care este nevoie la un moment dat pentru rezolvarea unei situații.

26 Cezar Popa, Structuri, sisteme, echipamente și tehnologii moderne în compunerea sistemelor de comandă și control, Raport de cercetare științifică nr. 1, Universitatea Națională de Apărare „Carol I”, București 2020, p. 34.

27 Pregătirea preventivă/prevenția și măsurile de adaptare.

28 Măsuri proactive din punct de vedere tactic, urmărind să descurajeze un adversar să atace sau să contracareze efectiv efectul unui atac.

29 Monolitic, - $\breve{a}$, monolitici, -ce, adj. Privitor la monolit; de monolit. Bine închegat, unitar, Dicționarul explicativ al 
Limbii Române, https://dexonline.ro/definitie/monolitic, accesat la 11.11.2021.

30 Zona dintre pace şi război sau Război neregulat. Tacticile utilizate sunt fluxurile de informaţie și canalele de influenţă, alături de cele cibernetice, economice și psihologice, cu implicarea opiniei publice, moralei şi proceselor legale, https://adevarul.ro/international/asia/ china-poarta-razboi-neregulat-sua-principiile-inarmariizona-gri-1 609a101a5163ec4271e9ae60/index.html, accesat la 09.11.2021.

31 James Mattis, Summary of the 2018 National Defense Strategy of the United States of America, Washington DC, DoD, 2018, p. 7, https://dod.defense.gov/Portals/1/Documents/ pubs/2018-National-Defense-Strategy-Summary.pdf, accesat la 27.10.2021.

32 Robert Leonhard, The Art of Maneuver, Maneuver Warfare Theory and AirLand Battle, Ballantine Books, New York, 1991, pp. 66-74.

33 Tiago Cavalcanti, Chryssi Giannitsarou, Charles R. Johnson, "Network Cohesion", Economic Theory 64, no. 1, 2017.

34 DARPA, Strategic Technology Office Outlines Vision for Mosaic Warfare, August 4, 2017, https://www.darpa.mil/ news-events/2017-08-04, accesat la 25.10.2021.

35 Bryan Clark, Dan Patt, Harrison Schramm, Mosaic Warfare expoiting artificial intelligence and autonomous systems to implement decision - centric operations, Center for Strategic and Budgetary Assessments, 2020, p. 16.

36 Pentru a crește numărul de participanţi care au câștigat experiență cu designul forței Mosaic și C2 aferent, forța Mosaic a fost împărțită între trei echipe Mosaic. Echipa Tradițională a primit întreaga forță tradițională.

37 Bryan Clark, Dan Patt, Harrison Schramm, Mosaic Warfare expoiting artificial intelligence and autonomous systems to implement decision - centric operations, Center for Strategic and Budgetary Assessments, 2020, p. 17.

38 Echipament de bruiaj.

39 Platforme inteligente din ce în ce mai complexe, cu dependență redusă de platforme monolitice.

40 Bryan Clark, Dan Patt, Harrison Schramm, op.cit., p. 37.

41 Cheryl Pellerin, Project Maven Industry Day Pursues Artificial Intelligence for DoD Challenges, DoD Newsroom, 2017, https://www.defense.gov/Newsroom/ News/Article/Article/1356172/project-maven-industry-daypursues-artificial-intelligence-for-dod-challenges/, accesat la 01.11.2021.

42 Charles W. Sasser, "The F-117 Nighthawk's NearPerfect Combat Record", Military Times, 2018; David Johnson, "An Army Caught în the Middle Between Luddites, Luminaries, and the Occasional Looney", War on the Rocks, 2018.

43 [US Joint Staff], Charter of The Joint Requirements Oversight Council (JROC) and Implementation of The Joint Capabilities Integration and Development System (JCIDS), CJCSI 5123.01H, 2018, pp. D-1-D-3; DoD, The Defense Acquisition System, DoDD 5000.01, 2018, http:// acqnotes. com/wp-content/uploads/2018/11/CJCSI-5123.01H-Charterof-the-Joint-Requirements-Oversight-Council JROC-andImplementation-of-the-JCIDS-31-Aug-2018.pdf, accesat la 04.11.2021.

44 Bryan Clark, Dan Patt, Harrison Schramm, op.cit., p. 47.

\section{BIBLIOGRAFIE}

*** Brussels Summit Declaration, 2018. *** NATO Allied Joint Doctrine for Intelligence

Procedures AJP-2.1.

***NATO Allied Joint Doctrine for Intelligence, Counter-Intelligence and Security AJP-2(A).

*** Russian Exoskeleton Project, Russia's latest combat exoskeleton to boost fire accuracy by 20\%, TASS Russian news agency, 2021.

[DARPA], Strategic Technology Office Outlines Vision for Mosaic Warfare, August 4, 2017, https:// www.darpa.mil/news-events/2017-08-04

[US Joint Staff], Charter of The Joint Requirements Oversight Council (JROC) and Implementation of The Joint Capabilities Integration and Development System (JCIDS), CJCSI 5123.01H, 2018; DoD, The Defense Acquisition System, DoDD 5000.01, 2018, http://acqnotes.com/ wp-content/uploads/2018/11/CJCSI-5123.01HCharter-of-the-Joint-Requirements-OversightCouncil JROC-and-Implementation-of-the-JCIDS31-Aug-2018.pdf

Blandy, North Caucasus, The Advent of Mountain Brigades, Defence Academy of the United Kingdom, 2007.

Cavalcanti Tiago, Giannitsarou Chryssi, Johnson R. Charles, "Network Cohesion", Economic Theory 64, no. 1, 2017.

Clark Bryan, Patt Dan, Schramm Harrison, Mosaic Warfare expoiting artificial intelligence and autonomous systems to implement decision - centric operations, Center for Strategic and Budgetary Assessments, 2020.

Johnson David, "An Army Caught in the Middle Between Luddites, Luminaries, and the Occasional Looney", War on the Rocks, 2018.

Lehaci Niculai-Tudorel, Tendințe în evoluția sistemului de comandă și control la nivel operativ, Editura Universităţii Naționale de Apărare „Carol I", București, 2015.

Leonhard Robert, The Art of Maneuver: Maneuver Warfare Theory and AirLand Battle, Ballantine Books, New York, 1991.

Mattis James, Summary of the 2018 National Defense Strategy of the United States of America, Washington DC, DoD, 2018, https://dod.defense. gov/Portals/1/Documents/pubs/2018-NationalDefense-Strategy-Summary.pdf 
Pellerin Cheryl, Project Maven Industry Day Pursues Artificial Intelligence for DoD Challenges, DoD Newsroom, 2017, https://www.defense. gov/Newsroom/News/Article/Article/1356172/ project-maven-industry-day-pursues-artificialintelligence-for-dod-challenges/

Popa Cezar, Strategii, concepte şi procedee de eficientizare a procesului decizional, Raport de cercetare științifică nr.2, Universitatea Naţională de Apărare „Carol I”, București, 2021.

Popa Cezar, Structuri, sisteme, echipamente și tehnologii moderne in compunerea sistemelor de comandă şi control, Raport de cercetare științifică nr. 1, Universitatea Națională de Apărare „Carol I”, București 2020.

Sasser W. Charles, "The F-117 Nighthawk's Near-Perfect Combat Record", Military Times, 2018.
https://unep.ch/publications/UNEP_Afghanistan_ NRM_guidance

https://www.defense.gov/Newsroom/News/ Article/Article/1356172/project-maven-industryday-pursues-artificial-intelligence-for-dodchallenges/

http://acqnotes.com/wp-content/uploads/2018/11/ CJCSI-5123.01H-Charter-of-the-Joint-Requirements -Oversight-Council JROC-and-Implementationof-the-JCIDS-31-Aug-2018

https://dod.defense.gov/Portals/1/Documents/ pubs/2018-National-Defense-Strategy-Summary https://www.darpa.mil/news-events/2017-08-04 https://adevarul.ro/international/asia/chinapoarta-razboi-neregulat-sua-principiile-inarmariizona-gri-1_609a101a5163ec4271e9ae60/index.html https://dexonline.ro/ 